\begin{tabular}{l} 
SCIENCE \& TECHNOLOGY \\
Journal homepage: http://www.pertanika.upm.edu.my/ \\
\hline PERTANIKA
\end{tabular}

Review article

\title{
Potential of Syzygium polyanthum (Daun Salam) in Lowering Blood Glucose Level: A Review
}

\author{
Nur Salsabeela Mohd Rahim, Ida Farah Ahmad and Terence Yew Chin Tan* \\ Herbal Medicine Research Centre, Institute for Medical Research, National Institutes of Health, \\ Ministry of Health Malaysia, Setia Alam, 40170 Shah Alam, Malaysia
}

\begin{abstract}
Syzygium polyanthum is a herb widely used in Malaysia and Indonesia in cuisines. Traditionally, the herbal decoction of $S$. polyanthum (daun salam) leaves is often used by diabetic patients in Indonesia. Therefore, our objective is to evaluate the scientific evidence available for $S$. polyanthum in lowering blood glucose levels (BGL). We systematically searched Pubmed, Google Scholar, Scopus, CENTRAL. LILAC and clinicaltrials.gov databases up to $23^{\text {rd }}$ October 2020 using the keywords "Syzygium polyanthum" and "antidiabetic". From the selected 413 articles, eight studies involving rodents were included. All results showed a significant effect in lowering BGL without any adverse effects. The possible underlying mechanism of action is attributed to inhibiting intestinal glucose absorption and enhancing glucose uptake by the muscles. Chemical families responsible for the effect were determined as flavonoids, alkaloids and terpenoids. Thus, S. polyanthum leaves showed potential antidiabetic properties, but further research is required to identify the active compounds followed by the safety evaluation of this compound.
\end{abstract}

Keywords: Blood glucose level, daun salam, diabetic, Syzygium polyanthum

\begin{tabular}{|c|c|}
\hline & INTRODUCTION \\
\hline ARTICLE INFO & Diabetes mellitus (DM) is described as a \\
\hline Article history: & deficiency of insulin production secreted \\
\hline $\begin{array}{l}\text { Received: } 03 \text { November } 2020 \\
\text { Accepted: } 08 \text { January } 2021\end{array}$ & by the pancreas or the inability of the body \\
\hline Published: 22 September 2021 & to use the insulin it produces (WHO, 2019). \\
\hline DOI: https://doi.org/10.47836/pjst.29.4.02 & There are currently 420 million people \\
\hline $\begin{array}{l}\text { E-mail addresses: } \\
\text { sectradknow.hmr@@moh.gov.my (Nur Salsabeela Mohd Rahim) } \\
\text { idafarah@moh.gov.my (Ida Farah Ahmad) } \\
\text { terencetyc@moh.gov.my (Terence Yew Chin Tan) } \\
\text { * Corresponding author }\end{array}$ & $\begin{array}{l}\text { globally with diabetes, with a mortality } \\
\text { rate of } 1.6 \text { million in } 2016 \text { (Loke, 2020). } \\
\text { This increase will occur due to population }\end{array}$ \\
\hline
\end{tabular}


growth, ageing, unhealthy diets, obesity and sedentary lifestyles (WHO, 2019). Asian countries make up more than $60 \%$ of the world's diabetic population (Ramachandran et al., 2012). This situation is due to a few factors, such as urbanisation and socioeconomic transition. Hence, they are prone to have more intra-abdominal fat accumulation and low muscle mass (Ramachandran et al., 2012).

According to the National Health and Morbidity Survey 2019 (NHMS, 2019), almost one in five Malaysian adults has diabetes. In addition, the survey found that 3.9 million Malaysian adults were diagnosed with diabetes, surpassing the 2014 prediction by Health Ministry that figure would not be reached until 2020 (Rashid, 2017).

There are two types of diabetes: Type 1 and Type 2. Type 1 diabetes (or juvenile/ childhood-onset diabetes) is defined as the failure of the pancreas to produce insulin caused by hereditary factors or damage to the immune system (Berawi et al., 2017; WHO, 2019; \& Widyawati et al., 2015a). Type 2 diabetes (non-insulin-dependent or adult-onset diabetes) is defined as the body's inability to respond appropriately to the action of insulin. Type 2 diabetes is much more common worldwide, accounting for around $90 \%$ of all diabetic patients, due to food intake habits, obesity, smoking and lack of physical activity (Berawi et al., 2017; WHO, 2019; \& Widyawati et al., 2015a).

Despite using insulin and oral medications to control blood glucose, diabetes remains among the world's top 10 causes of death (Waly et al., 2010; WHO, 2019; \& Widharna et al., 2015). In addition, DM is a risk factor for kidney, liver, and also contributes to the two-fold increase of coronary heart disease and vascular damage, which lead to $50 \%$ to $80 \%$ of the diabetes patient mortality (Emerging Risk Factors Collaboration, 2011; Duncan et al., 2003; Nwaneri et al., 2013; Rashid, 2017; \& Whiteley et al., 2005).

Syzygium polyanthum belongs to the Myrtaceae family (The Plant List, 2012; Quattrocchi, 2012). Among others, species included in the genus Syzygium are Eugenia atropunctata, Eugenia holmanii, Eugenia balsamea, Syzygium cymosum, Syzygium micranthum, and Syzygium pamatense (The Plant List, 2012; Quattrocchi, 2012). S. polyanthum is widely distributed throughout Myanmar, Indo-China, Thailand, Malaysia, and Indonesia (Azwar, 2010), with a few familiar names, such as Indian laurel, Indonesian bay leaf, daun salam, kelat samak, samak, serah, serai kayu, kelat putih, kelat merah, palong (Malaysia), manting, salam, and ubar serai (Indonesia) (Malaysian Herbal Monograph Committee, 2017; The Plant List, 2012; \& Quattrocchi, 2012).

Traditionally, S. polyanthum is widely used as a food ingredient in Indonesian and Malaysian cuisine and used to treat diabetes in Indonesia (Azwar, 2010). It is usually dried, crushed and extracted through soaking in boiled water (Dewijanti et al., 2018).

Other traditional uses include using the leaf and bark extracts of $S$. polyanthum for treating diarrhoea (Burkill, 1935). In addition, the poultices of the bark, root and leaves relieve itching (Burkill, 1935). The leaves contain polyphenols (flavonoids, terpenoids, 
tannins) and saponin (Hikmah et al., 2016; Liem et al., 2015; Wahjuni et al., 2018; Widharna et al., 2015; Widyawati et al., 2015a \& Yuliana, 2014). In medicinal plants. These polyphenols, saponins and coumarins have been reported to exhibit antidiabetic properties (Hikmah et al., 2016; Wahjuni et al., 2018; Yuliana, 2014).

Since $S$. polyathum leaves are ethnobotanically used in treating diabetes in Indonesia and Malaysia (Dewijanti, 2018 \& Burkill, 1935), the National Agency for Drug and Food Control in Indonesia highly regards this medicinal plant. Therefore, we conducted this study to evaluate the scientific evidence available for $S$. polyanthum in lowering blood glucose levels (BGL).

\section{MATERIALS AND METHODS}

This review was conducted under the Preferred Reporting Items for Systematic Reviews and Meta-Analysis (PRISMA) guidelines (Liberati et al., 2009).

\section{Search Strategy}

A literature search was conducted to identify relevant studies on S. polyanthum in lowering blood glucose. The following six electronic databases were searched for this purpose: Pubmed, Google Scholar, Scopus, CENTRAL, LILAC, and clinicaltrials.gov with two keywords (Syzygium polyanthum and antidiabetic) and their combinations (Table 1). The bird's eye view strategy was applied to identify all the antidiabetic properties of S. polyanthum. Relevant studies were further identified by going through the citations and lists of references in the related articles. All related articles found in English and Indonesian were included. Two authors independently conducted the literature search by dividing the databases list and followed by cross-checking to avoid redundancy. The search was done up to $23^{\text {rd }}$ October 2020. The tentatively selected articles were reviewed for the inclusion criteria, peer-reviewed, and the articles that best met the criteria were carefully selected. The extensive literature search brought about 413 published articles (Table 1).

\section{Study Selection}

The PICOS (participants/patients, interventions, comparators, outcomes, study design) formula for the literature search was pre-determined through discussion by the authors. The selection of search terms was centred on participants and interventions for maximum sensitivity, as shown in Table 1. The search and inclusion/exclusion criteria are reported according to the Preferred Reporting Items for Systematic Reviews and Meta-Analyses (PRISMA) guidelines and presented in a PRISMA flow chart in Figure 1. The abstract of the searched articles was screened, followed by full-text reading for articles fulfilling the inclusion criteria. The inclusion criteria were based on samples, intervention, outcomes and study design. Articles published in English and Indonesian were reviewed and extracted. 
Two authors conducted the screening process. Any disagreement was discussed with the third author, and a decision is agreed on. Both authors worked independently in analysing the eight studies and tabulated the extracted data (Table 2), and subsequently critically appraised the chosen papers together to reduce bias.

\section{Selection of Samples and Intervention}

1. Types of study sample: This review included using S. polyanthum as an intervention in animals induced with diabetes.

2. Types of intervention selected for this review include studies using any form/dosage of $S$. polyanthum intervention comparing it with diabetic medications.

3. Types of comparison: The comparison groups included (a) group with $S$. polyanthum compared with glibenclamide, (b) group with S. polyanthum compared with metformin, and (c) group with a combination of $S$. polyanthum with glibenclamide.

\section{Selection of Outcomes}

The outcome selected was the intervention ability and the comparators of $S$. polyanthum for lowering BGL in Type 2 diabetes in experimental studies.

\section{Selection of Study Model}

In vivo and human trials (if any) that evaluated the effectiveness of S. polyanthum in lowering BGL were included in this review.

\section{Quality Assessment of Included Studies}

The risk of bias (RoB) tool for animal intervention studies, i.e. SYRCLE's RoB tool, was used to assess the risk of bias of all included studies (Hooijmans et al., 2014b). Two independent authors performed a quality assessment of all included studies. Disagreements were resolved by discussion.

\section{RESULTS}

The search initially produced 413 potentially relevant studies (Table 1). However, 22 review articles were excluded immediately from these articles, as these contributed no additional data besides the original studies, which were already included. Another 111 studies were excluded based on duplication, vague references and unpublished work. Of the remaining 280 studies, 75 did not include antidiabetic studies, 120 did not use $S$. polyanthum species, and 77 involved other than in vivo studies. Conclusively, eight articles that fulfilled the inclusion criteria were included in this review (Hikmah et al., 2016; Liem 
et al., 2015; Sutrisna et al., 2016; Wahjuni et al., 2018; Widharna et al., 2015; Widyawati et al., 2015a; Widyawati et al., 2015a; \& Yuliana, 2014), as shown in the process of study selection (Figure 1).

The selected studied all used leaves extract of $S$. polyanthum in the form of extracts or decoction (Hikmah et al., 2016; Liem et al., 2015; Sutrisna et al., 2016; Wahjuni et al., 2018; Widharna et al., 2015; Widyawati et al., 2015a; Widyawati et al., 2015b; \& Yuliana, 2014) and had comparable designs: in lowering BGL (Hikmah et al., 2016; Liem et al., 2015; Sutrisna et al., 2016; Wahjuni et al., 2018; Widharna et al., 2015; Widyawati et

Table 1

Search strategies used

\begin{tabular}{lccc}
\hline Databases & Year of search & Keyword used & $\begin{array}{c}\text { No. of studies in } \\
\text { search }\end{array}$ \\
\hline Pubmed & $2015-2020$ & Syzygium polyanthum AND antidiabetic & 3 \\
Google scholar & $2005-2020$ & Syzygium polyanthum AND antidiabetic & 295 \\
Scopus & $2005-2020$ & Syzygium polyanthum AND antidiabetic & 71 \\
CENTRAL & 2019 & Syzygium polyanthum AND antidiabetic & 1 \\
LILAC & (No hit) & Syzygium polyanthum AND antidiabetic & 0 \\
Clinicaltrials.gov & $2009-2020$ & Syzygium polyanthum AND antidiabetic & 43 \\
\hline TOTAL SEARCH $=$ & & & 413 \\
\hline
\end{tabular}

Note. As of $8^{\text {th }}$ September 2020

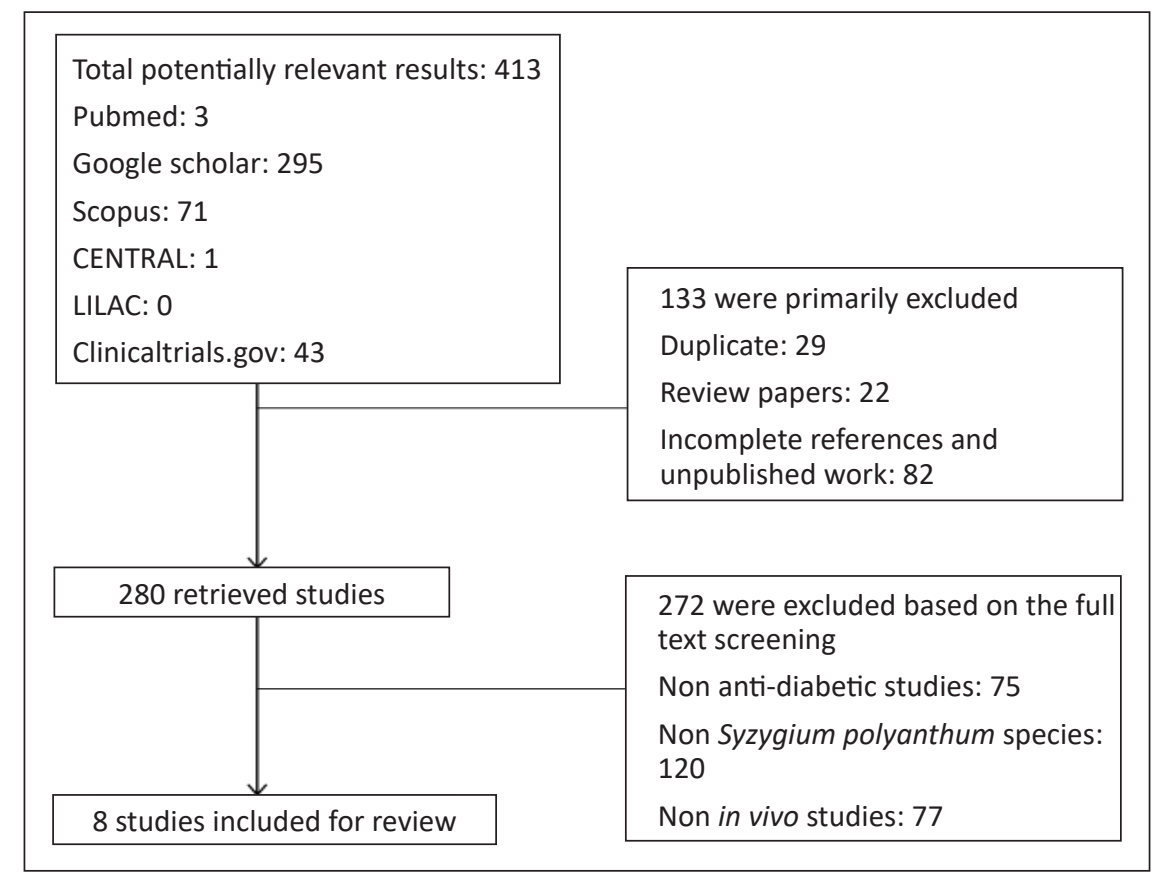

Figure 1. Preferred Reporting Items for Systematic Reviews and Meta-Analysis (PRISMA) flow diagram of study selection 
al., 2015a; Widyawati et al., 2015b; \& Yuliana, 2014), fasted animals were first induced with diabetes using alloxan (Hikmah et al., 2016; Liem et al., 2015; Sutrisna et al., 2016; Wahjuni et al., 2018; Widharna et al., 2015; Widyawati et al., 2015a; \& Yuliana, 2014) or streptozotocin (Widyawati et al., 2015a \& 2015b) followed by S. polyanthum mixture with glibenclamide (Hikmah et al., 2016 \& Liem et al., 2015), different dosages of S. polyanthum extract alone (Sutrisna et al., 2016; Wahjuni et al., 2018; Widharna et al., 2015; Widyawati et al., 2015b; \& Yuliana, 2014) or different extracts of S. polyanthum (Widyawati et al., 2015a) supplementation for a duration of 6 to 56 days. Only one study had a test period of seven hours (Widyawati et al., 2015a).

The results showed that oral administration of methanol extract of $S$. polyanthum leaves (1000 mg/kg body weight) did not significantly alter BGL in normal or intraperitoneally glucose-loaded male Sprague Dawley rats. However, in streptozotocin-induced (55 mg/ $\mathrm{kg}$ b.w.) diabetic male Sprague Dawley rats (180 g to $250 \mathrm{~g}$ ), administration of the extract in three doses $(250,500,1000 \mathrm{mg} / \mathrm{kg}$ b.w.) twice daily for six days significantly $(\mathrm{p}<0.05$, $\mathrm{p}<0.01, \mathrm{p}<0.001)$ and dose-dependently reduced fasting BGL compared to the control (normal saline, $10 \mathrm{~mL} / \mathrm{kg}$ b.w.) (Widyawati et al., 2015b).

The aqueous extract of $S$. polyanthum leaves $(200 \mathrm{mg} / \mathrm{kg}$ b.w.) administered orally to intravenous glucose-loaded average male Wistar rats (100 g to $150 \mathrm{~g}$ ) showed a significantly $(\mathrm{p}<0.01)$ reduction in BGL after 30 minutes. Glibenclamide administered at $0.45 \mathrm{mg} / \mathrm{kg}$ b.w. on the other hand, significantly $(\mathrm{p}<0.01)$ reduced the BGL after 90 minutes compared to the regular control group (received drinking water) (Widharna et al., 2015).

Aqueous extract of $S$. polyanthum leaves $(200 \mathrm{mg} / \mathrm{kg}$ b.w.) administrated orally to alloxan-induced (150 mg/kg b.w.) diabetic male Wistar rats (100 g to $150 \mathrm{~g})$ for 14 days significantly $(\mathrm{p}<0.01)$ reduced their fasting BGL to $45 \%$ compared to untreated diabetic rats that received drinking water. However, oral administration of metformin $(63 \mathrm{mg} / \mathrm{kg}$ b.w.) reduced fasting BGL to $48 \%$, which showed no significant difference with the S. polyanthum extract (Widharna et al., 2015).

The combination of ethanol extract of $S$. polyanthum leaves $(500 \mathrm{mg} / \mathrm{kg}$ b.w. and 750 $\mathrm{mg} / \mathrm{kg} \mathrm{b.w.)} \mathrm{with} \mathrm{glibenclamide}(0.65 \mathrm{mg} / \mathrm{kg}$ b.w.) administrated orally to alloxan-induced (120 mg/kg b.w.) diabetic mice (Mus musculus) for 14 days significantly $(\mathrm{p}<0.05)$ lowered fasting BGL by $230 \pm 23.69$ and $233.75 \pm 9.93 \mathrm{mg} / \mathrm{dL}$. This result is significant compared to the negative control ( $\mathrm{Na}$ carboxymethyl cellulose (CMC) $0.5 \%$ ) by $4 \pm 6.82 \mathrm{mg} / \mathrm{dL}$, positive control (glibenclamide alone) by $150.75 \pm 11.34 \mathrm{mg} / \mathrm{dL}$, combination of ethanol extract of $S$. polyanthum leaves $(250 \mathrm{mg} / \mathrm{kg} \mathrm{b.w.)} \mathrm{with} \mathrm{glibenclamide}(0.65 \mathrm{mg} / \mathrm{kg} \mathrm{b.w}$.) by $170 \pm 10.51 \mathrm{mg} / \mathrm{dL}$, and ethanol extract of $S$. polyanthum alone of 250,500 and 750 $\mathrm{mg} / \mathrm{kg}$ b.w. at $134 \pm 4.61,151.25 \pm 6.72$, and $158.75 \pm 17.64 \mathrm{mg} / \mathrm{dL}$, respectively (Liem et al., 2015).

The leaf decoction of $S$. polyanthum (1800 mg/kg b.w.) administrated orally to alloxan-induced (120 mg/kg b.w.) diabetic male Wistar rats (180 gm to $200 \mathrm{~g}$ ) for ten days 
significantly $(\mathrm{p}<0.05)$ lowered fasting BGL on hyperglycaemic rats as well as Kupffer cell count. However, it is not likely to give significant results in lowering pancreatic and kidney haemorrhage scores (Yuliana, 2014).

Petroleum ether, chloroform, and methanol extract of $S$. polyanthum leaves at a dose of $1000 \mathrm{mg} / \mathrm{kg}$ b.w. administrated orally to intraperitoneal glucose-loaded average male Sprague Dawley rats ( $180 \mathrm{~g}$ to $250 \mathrm{~g}$ ) for 30 minutes did not significantly alter the increase of BGL within 120 minutes after glucose loading (Widyawati et al., 2015a).

Aqueous extract of $S$. polyanthum leaves at a dose of $(1000 \mathrm{mg} / \mathrm{kg} \mathrm{b.w.)} \mathrm{administrated}$ orally to intraperitoneal glucose-loaded average male Sprague Dawley rats (180 g to 250 $\mathrm{g})$ for 30 minutes significantly $(\mathrm{p}<0.05)$ increase BGL $(9.3 \pm 0.38 \mathrm{mmol} / \mathrm{L})$ compared to the control (normal saline, $10 \mathrm{~mL} / \mathrm{kg}$ b.w.). Metformin with the administration of 500 $\mathrm{mg} / \mathrm{kg}$ b.w. dose, on the other hand, significantly displayed better BGL inhibition after 90 minutes $(\mathrm{p}<0.01)(5.3 \pm 0.14 \mathrm{mmol} / \mathrm{L})$ and 120 minutes $(\mathrm{p}<0.05)(5.1 \pm 0.19 \mathrm{mmol} / \mathrm{L})$ compared to the control (normal saline, $10 \mathrm{~mL} / \mathrm{kg}$ b.w.) with $6.4 \pm 0.23 \mathrm{mmol} / \mathrm{L}$ after 90 minutes and $5.9 \pm 0.13 \mathrm{mmol} / \mathrm{L}$ after 120 minutes (Widyawati et al., 2015a).

Methanol extract of $S$. polyanthum leaves $(1000 \mathrm{mg} / \mathrm{kg}$ b.w.) administrated orally to streptozotocin-induced (55 mg/kg b.w.) diabetic male Sprague Dawley rats (180 g to $250 \mathrm{~g})$ for seven hours significantly $(\mathrm{p}<0.01)$ decrease the fasting BGL compared to the diabetic control (normal saline, $10 \mathrm{~mL} / \mathrm{kg}$ b.w.). Metformin, on the other hand, significantly reduced the blood glucose from the first hour $(p<0.01)$ to the seventh hour $(p<0.001)$ of the study (Widyawati et al., 2015a).

Ethanol extract of $S$. polyanthum leaves $(62.5,125$, and 250$) \mathrm{mg} / \mathrm{kg}$ b.w. administrated orally to alloxan-induced $(150 \mathrm{mg} / \mathrm{kg} \mathrm{b.w.)} \mathrm{diabetic} \mathrm{male} \mathrm{Wistar} \mathrm{rats} \mathrm{for} \mathrm{ten} \mathrm{days}$ significantly $(\mathrm{p}<0.05)$ reduced BGL $(114.3 \pm 9.4,119.3 \pm 23.4,119.3 \pm 11.3) \mathrm{mg} / \mathrm{dL}$ (Sutrisna et al., 2016).

The combination of ethanol extract of $S$. polyanthum leaves $(750 \mathrm{mg} / \mathrm{kg} \mathrm{b.w.)}$ and glibenclamide ( $0.65 \mathrm{mg} / \mathrm{kg}$ b.w.) administrated orally to alloxan-induced (70 mg/kg b.w.) diabetic male mice (Mus musculus) for 14 days shows significant $(\mathrm{p}>0.05)$ mean difference of lowered fasting BGL $(287.4 \pm 65.05 \mathrm{mg} / \mathrm{dL})$ compared to the negative control (Na CMC $0.5 \%$ ) showing $-78.8 \pm 115.12 \mathrm{mg} / \mathrm{dL}$, positive control (glibenclamide alone) (173.6 \pm 60.55 $\mathrm{mg} / \mathrm{dL})$, ethanol extract of $S$. polyanthum leaves alone at $(250,500$ and 750$) \mathrm{mg} / \mathrm{kg} \mathrm{b.w}$. with $135.4 \pm 28.89,163.2 \pm 47.99,190.2 \pm 46.98 \mathrm{mg} / \mathrm{dL}$ mean difference respectively, and the combination of ethanol extract of $S$. polyanthum leaves ( 250 and 500$) \mathrm{mg} / \mathrm{kg} \mathrm{b.w}$. with glibenclamide (0.65 mg/kg b.w.) (237.4 $\pm 75.11,246 \pm 23.09) \mathrm{mg} / \mathrm{dL}$ (Hikmah et al., 2016).

Aqueous extract of $S$. polyanthum leaves $(5.0 \mathrm{mg} / \mathrm{kg}$ b.w./day) administrated orally to alloxan-induced $(125 \mathrm{mg} / \mathrm{kg}$ b.w.) diabetic Wistar rats for 56 days significantly ( $\mathrm{p}<$ $0.05)$ lowered BGL $(110.56 \pm 1.68 \mathrm{mg} / \mathrm{dL})$ than the control group $(105.76 \pm 2.53 \mathrm{mg} / \mathrm{dL})$ (Wahjuni et al., 2018). 
Figures 2 and 3 show the risk of bias assessment results of the eight studies included in this review. Six (75\%) of the studies stated the studies have baseline characteristics based on this assessment. Since the backgrounds of the animals were essentially homogeneous,

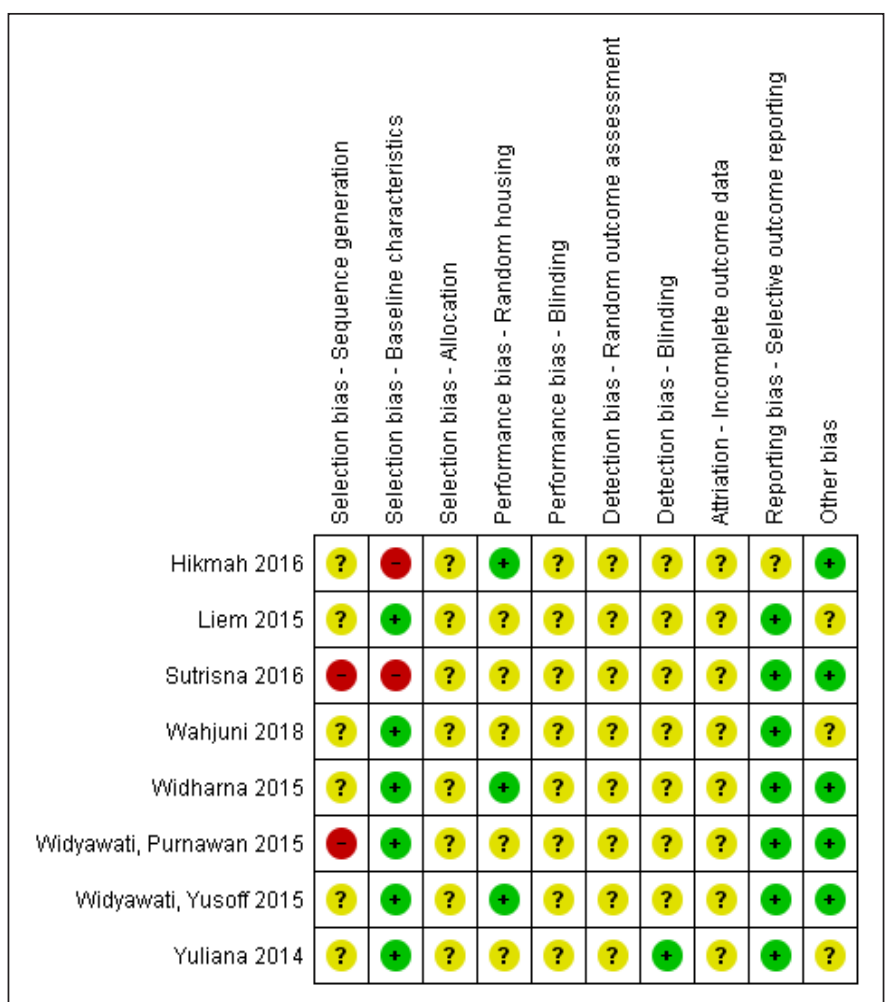

Figure 2. Risk of bias assessment of included studies using SYRCLE tool

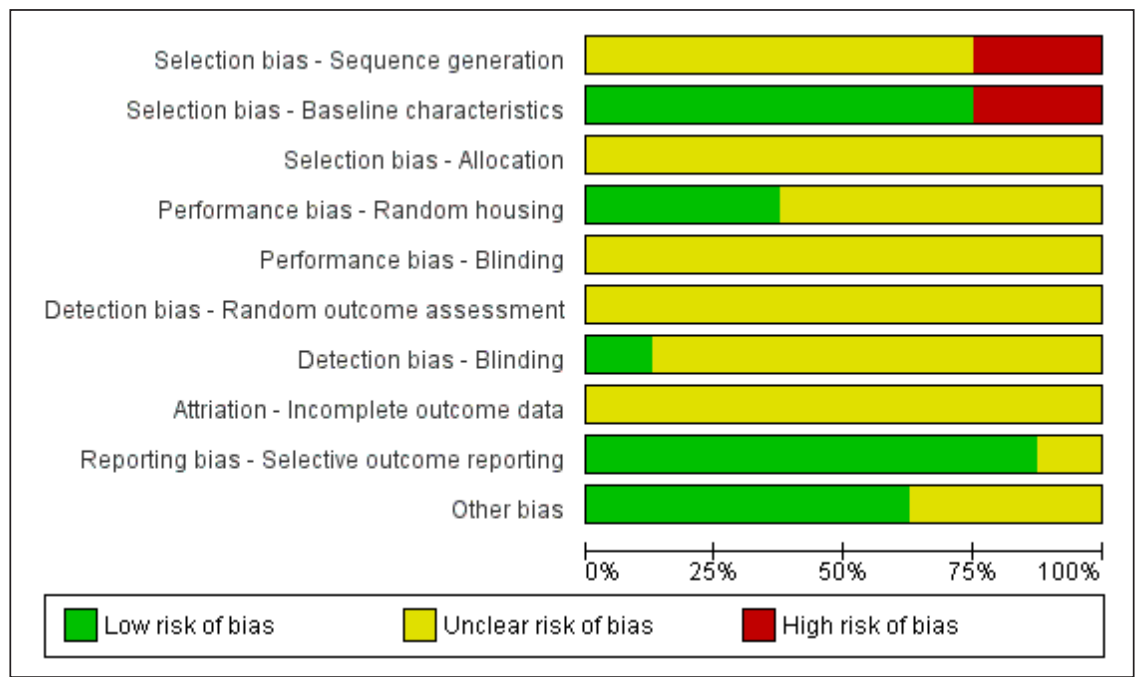

Figure 3. Risk of bias summary 
Potential of S. polyanthum in Lowering Blood Glucose Level: A Review

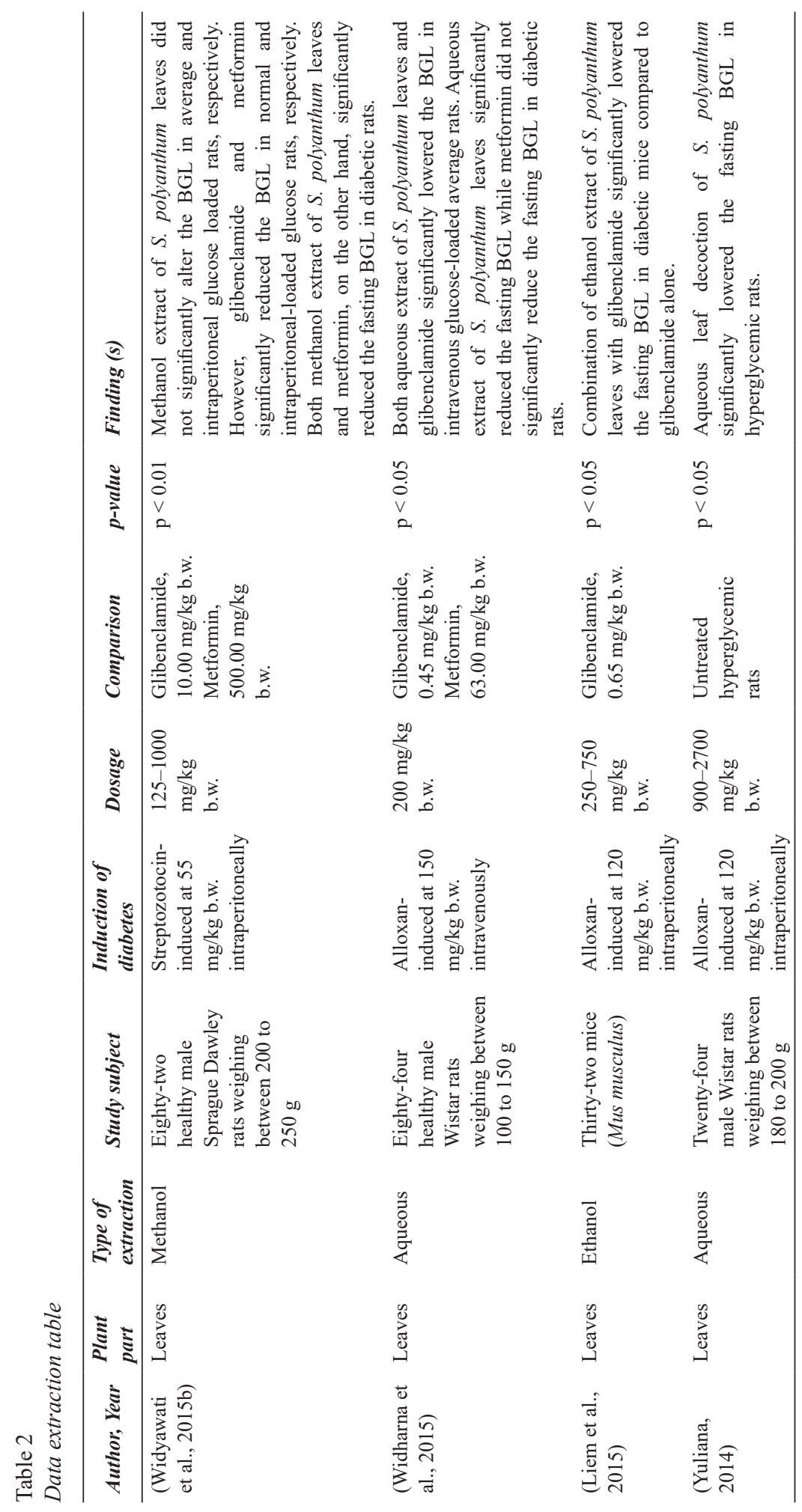

Pertanika J. Sci. \& Technol. 29 (4): 2261 - 2277 (2021) 


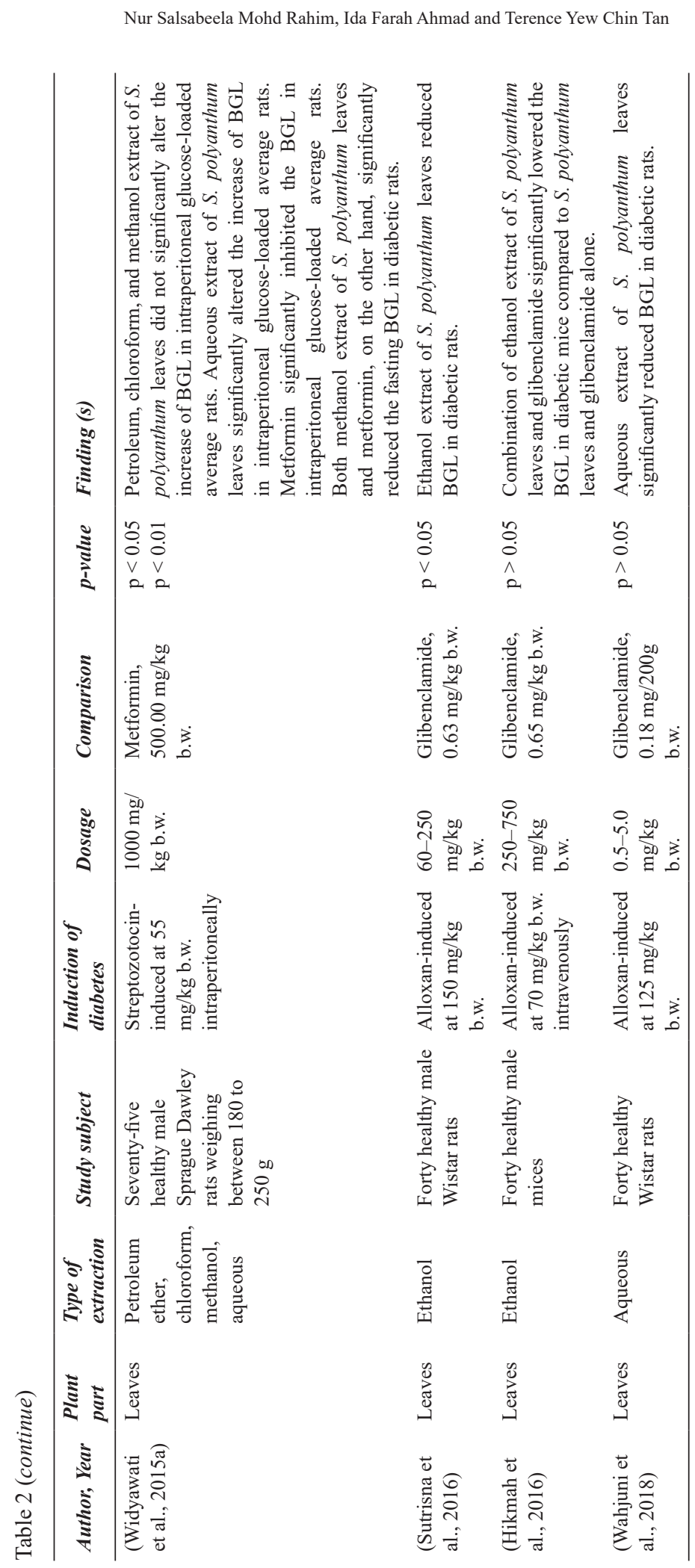


most of the studies did not describe the method of randomisation. None of the studies indicated whether the allocation was adequately concealed. As shown clearly in Figure 2, many items were scored as "unclear", indicating that these animal studies' reporting and presumably experimental design can be improved. Three (38\%) of the studies did not state the source of the plant or extract, which gives a score of "unclear" in other bias.

\section{DISCUSSION}

Of the total eight studies we analysed, we found that different extracts of $S$. polyanthum leaves (aqueous, methanol, and ethanol) positively impact lowering the BGL in animal subjects. Out of the eight studies, the $S$. polyanthum leaves extract were conducted in average and diabetic rats to examine the hypoglycaemic (three studies) (Widharna et al., 2015; Widyawati et al., 2015a; \& Widyawati et al., 2015b), intraperitoneal glucose tolerance test IPGTT (two studies) (Widyawati et al., 2015a \& 2015b) and antihyperglycaemic (eight studies) (Hikmah et al., 2016; Liem et al., 2015; Sutrisna et al., 2016; Wahjuni et al., 2018; Widharna et al., 2015; Widyawati et al., 2015a; Widyawati et al., 2015b; \& Yuliana, 2014). In addition, Sutrisna et al. (2016) reported that the most optimum dosage of ethanol extract of $S$. polyanthum leaves $(62.5 \mathrm{mg} / \mathrm{kg}$ b.w.) administered to male Wistar rats reduced the BGL to $114.3 \pm 9.4 \mathrm{mg} / \mathrm{dL}$.

The phytochemical screening of $S$. polyanthum leaves extract contains tannins, flavonoids, alkaloids, and terpenoids (Hikmah et al., 2016; Liem et al., 2015; Wahjuni et al., 2018; Widharna et al., 2015; Widyawati et al., 2015b; \& Yuliana, 2014). Each of these compounds has been shown to have a potential antidiabetic effect. A study reported that administering tannin from Syzygium mundagam bark significantly reduced the BGL of an STZ-induced diabetic rat model. It has been shown to have the antioxidant effect of tannin on reducing oxidative stress in diabetic animals supplemented with tannin fraction (TF) $200 \mathrm{mg} / \mathrm{kg}$ due to its hydrogen donating ability, which reduces the radical scavenging activity (Chandran et al., 2017; \& Velayutham et al., 2012).

Flavonoids have been reported to possess antihyperglycaemic activity in STZinduced diabetic rats through a few mechanisms of action attributable to the inhibition of $\alpha$-glucosidase and the elevation of blood insulin levels (Khamchan et al., 2018; \& Mohamed et al., 2015). Flavonoid compound (quercetin) present in Syzygium cumini seed (Chagas et al., 2015) and phenolic compound (gallic acid) present in Syzygium samarangense fruit (Khamchan et al., 2018) have been reported to regenerate pancreatic $\beta$-cells, thus may increase the secretion of insulin (Brahmachari, 2011; Jananie et al., 2011; \& Yang \& Kang, 2018). In addition, the animal study showed that flavonoids played similar functions to vitamin $\mathrm{E}$ by inhibiting peroxidation to liver microsomes in mice that experienced vitamin E efficiency (Duthie \& Morrice, 2012). It is due to the stimulation of antioxidant enzymes catalase (CAT) and superoxide dismutase (SOD) activities or chemical structure where 
double bond at two to three position conjugated with a 4-oxo function and hydroxyl groups at positions 3 and 5 in flavonoid contributes to its antiradical activity (Khamchan, 2018; Duthie \& Morrice, 2012).

Alkaloid from S. polyanthum leaves has shown antidiabetic potential in STZ-induced diabetic rats (Widyawati et al., 2015b). Alkaloid compounds, namely polyhydroxyalkaloids (PHA), specifically casuarine 6-O- $\alpha$-glucoside that are present in most Myrtaceae species such as Syzygium malaccense, Syzygium oleosum, Syzygium paniculatum, and Syzygium cumini. They could be induced in relatively high glucose uptake in mouse ( $\beta$-TC6) pancreatic cell line and mouse (C2C12) myoblast skeletal muscle cells (Bhaskar et al., 2011; Jung et al., 2006; Kumar et al., 2013; \& Porter et al., 2000). Alkaloid compounds play a role in reducing blood glucose transportation in the blood, stimulates glycogen synthesis and inhibits glucose synthesis by inhibiting enzyme glucose 6-phosphatase, fructose 1, 6-bifosfatasen and increase glucose oxidation through glucose 6-phosphate dehydrogenase (Kooti et al., 2016).

Oral administration of triterpenoid from Syzygium malaccense for 15 days results in a significant decrease of fasting BGL in STZ-induced diabetic rats (Bairy et al., 2005). Squalene, a triterpene that belongs to the terpenoid family present in $S$. polyanthum (Widyawati et al., 2015b) and Mucuna pruriens (Bhaskar et al., 2011), is responsible as an $\alpha$-glucosidase inhibitor (Hou et al., 2009), which delay the absorbance of carbohydrates in the intestine subsequently decreasing the postprandial insulin level and also increase insulin insensitivity (Li et al., 2010; Nazaruk \& Borzym-Kluczyk, 2014) and may increase insulin secretion (Li et al., 2010). Another underlying mechanism of $S$. polyanthum in reducing BGL may be inhibiting intestinal glucose absorption and enhancing glucose uptake by the muscles (Kooti et al., 2016).

However, few references suggest or deny the use of $S$. polyanthum leaves as a potential antidiabetic agent. The available articles have limitations in many aspects, and the results lack implications. Besides, no human studies are available, and only animal studies were included. Therefore, it is not easy to conduct any measure of consistency or subgroup analysis due to the more diverse nature of the animal studies, such as species used, design, and study characteristics (age, dose, schedule of administration). The risk of bias assessment of the animal studies conducted in this paper is vital to show the need to reduce the biases through methodological quality since most of the assessments gave "unclear" scores. Although safety data on S. polyanthum is limited, the only study by Widharna et al. (2015) revealed that combination of $S$. polyanthum and Andrographis paniculata leaves extract were free of acute oral toxicity up to $2000 \mathrm{mg} / \mathrm{kg}$ body weight and did not cause a change in behavioural activities of the animals. Other toxicity tests reported previously suggested that the extract of S. polyanthum was practically safe and non-toxic when tested on Wistar rats (Sumiwi et al., 2019). Therefore, based on the current empirical evidence, the potential 
of $S$. polyanthum leaves alone or combined with glibenclamide has shown a significant lowering of blood glucose levels. However, this paper showed the need to improve the methodological quality of animal studies. It can be done by minimising or standardising the biological study characteristics of animal studies and reducing bias sources. By performing this, the original research can be applicable with high quality to be used for meta-analysis with reduced impact of bias (Hooijmans et al., 2014a).

\section{CONCLUSION}

In conclusion, the extract of $S$. polyanthum leaves alone or combined with glibenclamide may potentially exhibit a significant antidiabetic effect. However, although the leaves extract of $S$. polyanthum may be a promising agent for diabetes mellitus, further studies with a comprehensive methodology and results are needed to determine the phytochemicals involved, possible mechanisms of action, and safety assessment so that the results can be translated into clinical trials.

\section{ACKNOWLEDGEMENT}

The authors wish to extend their gratitude to the Director General of Health Malaysia, the Deputy Director-General of Health (Research \& Technical Support), the Director of Institute for Medical Research, and the Head of Centre of Herbal Medicine Research Centre for their support and permission to publish this article.

\section{REFERENCES}

Azwar, A. (2010). Tanaman obat Indonesia (Buku kedua ed.) [Indonesia Medicinal Plants (2nd Ed.)]. Selemba Medika.

Bairy, K., Sharma, A., \& Shalini, A. (2005). Evaluation of the hypoglycemic, hypolipidemic and hepatic glycogen raising effects of Syzygium malaccense upon streptozotocin induced diabetic rats. Journal of Natural remedies, 5(1), 46-51. https://doi.org/10.18311/jnr/2005/414

Berawi, K. N., Shidarti, L., Nurdin, S. U., Lipoeto, N. I., \& Wahid, I. (2017). Comparison effectiveness of antidiabetic activity extract herbal mixture of soursop leaves (Annona muricata), bay leaves (Syzygium polyanthum) and pegagan leaves (Centella asiatica). Biomedical and Pharmacology Journal, 10(3), 1481-1488. https://dx.doi.org/10.13005/bpj/1256

Bhaskar, A., Nithya, V., \& Vidhya, V. (2011). Phytochemical evaluation by GC-MS and antihyperglycemic activity of Mucuna pruriens on streptozotocin induced diabetes in rats. Journal of Chemical and Pharmaceutical Research, 3(5), 689-696.

Brahmachari, G. (2011). Bio-flavonoids with promising antidiabetic potentials: A critical survey. Research Signpost, 661(2), 187-212.

Burkill, I. H. (1935). A dictionary of the economic products of the Malay Peninsula (Vol. I (A - H)). Crown Agents for the Colonies. 
Chagas, V. T., França, L. M., Malik, S., \& Paes, A. M. D. A. (2015). Syzygium cumini (L.) skeels: A prominent source of bioactive molecules against cardiometabolic diseases. Frontiers in Pharmacology, 6, Article 259. https://doi.org/10.3389/fphar.2015.00259

Chandran, R., Parimelazhagan, T., \& George, B. P. (2017). Antihyperglycemic activity of the bark methanolic extract of Syzygium mundagam in diabetic rats. Alexandria Journal of Medicine, 53(4), 317-324. https:// doi.org/10.1016/j.ajme.2016.12.001

Dewijanti, I. D., Artanti, N., Mangunwardoyo, W., Hanafi, M., Abbas, J., Megawati, M., Minarti, M., Musdalifah, D., \& Meilawati, L. (2018). Bioactivities of Syzygium polyanthum (Wight) Walp leaf extract for decreasing diabetic risk. In AIP Conference Proceedings (Vol. 2024, No. 1, p. 020011). AIP Publishing LLC. https://doi.org/10.1063/1.5064297

Duncan, B. B., Schmidt, M. I., Pankow, J. S., Ballantyne, C. M., Couper, D., Vigo, A., \& Heiss, G. (2003). Low-grade systemic inflammation and the development of type 2 diabetes: The atherosclerosis risk in communities study. Diabetes, 52(7), 1799-1805. https://doi.org/10.2337/diabetes.52.7.1799

Duthie, G., \& Morrice, P. (2012). Antioxidant capacity of flavonoids in hepatic microsomes is not reflected by antioxidant effects in vivo. Oxidative Medicine and Cellular Longevity, 2012, Article 165127. https:// doi.org/10.1155/2012/165127

Emerging Risk Factors Collaboration. (2011). Diabetes mellitus, fasting glucose, and risk of cause-specific death. New England Journal of Medicine, 364(9), 829-841. https://doi.org/10.1056/NEJMoa1008862

Hikmah, N., Yuliet, Y., \& Khaerati, K. (2016). Pengaruh pemberian ekstrak daun salam (Syzygium polyanthum Wight.) terhadap glibenklamid dalam menurunkan kadar glukosa darah mencit (Mus musculus) yang diinduksi aloksan [Effect of administration of bay leaf extract (Syzygium polyanthum Wight.) on glibenclamide in reducing blood glucose levels of mice (Mus musculus) induced by alloxan.]. Jurnal Farmasi Galenika (Galenika Journal of Pharmacy)(e-Journal), 2(1), 24-30.

Hooijmans, C. R., IntHout, J., Ritskes-Hoitinga, M., \& Rovers, M. M. (2014a). Meta-analyses of animal studies: An introduction of a valuable instrument to further improve healthcare. Institute for Laboratory Animal Research Journal, 55(3), 418-426. https://doi.org/10.1093/ilar/ilu042

Hooijmans, C. R., Rovers, M. M., de Vries, R. B., Leenaars, M., Ritskes-Hoitinga, M., \& Langendam, M. W. (2014b). SYRCLE's risk of bias tool for animal studies. BMC Medical Research Methodology, 14, Article 43. https://doi.org/10.1186/1471-2288-14-43

Hou, W., Li, Y., Zhang, Q., Wei, X., Peng, A., Chen, L., \& Wei, Y. (2009). Triterpene acids isolated from Lagerstroemia speciosa leaves as $\alpha$-glucosidase inhibitors. Phytotherapy Research: An International Journal Devoted to Pharmacological and Toxicological Evaluation of Natural Product Derivatives, 23(5), 614-618. https://doi.org/10.1002/ptr.2661

Jananie, R., Priya, V., \& Vijayalakshmi, K. (2011). Determination of bioactive components of Cynodon dactylon by GC-MS analysis. New York Science Journal, 4(4), 1-5.

Jung, M., Park, M., Lee, H. C., Kang, Y. H., Kang, E. S., \& Kim, S. K. (2006). Antidiabetic agents from medicinal plants. Current Medicinal Chemistry, 13(10), 1203-1218. https://doi.org/10.2174/092986706776360860 
Khamchan, A., Paseephol, T., \& Hanchang, W. (2018). Protective effect of wax apple [Syzygium samarangense (Blume) Merr. \& LM Perry] against streptozotocin-induced pancreatic ß-cell damage in diabetic rats. Biomedicine \& Pharmacotherapy, 108, 634-645. https://doi.org/10.1016/j.biopha.2018.09.072

Kooti, W., Farokhipour, M., Asadzadeh, Z., Ashtary-Larky, D., \& Asadi-Samani, M. (2016). The role of medicinal plants in the treatment of diabetes: A systematic review. Electronic Physician, 8(1), 1832-1842. https://doi.org/10.19082/1832

Kumar, A., Ilavarasan, R., Jayach, T., Deecaraman, M., Aravindan, P., Padmanabhan, N., \& Krishan, M. (2013). Anti-diabetic activity of Syzygium cumini and its isolated compound against streptozotocin-induced diabetic rats. Journal of Medicinal Plants Research, 2(9), 246-249. https://doi.org/10.5897/JMPR.9000093

Li, T. H., Hou, C. C., Chang, C. L. T., \& Yang, W. C. (2010). Anti-hyperglycemic properties of crude extract and triterpenes from Poria cocos. Evidence-Based Complementary and Alternative Medicine, 2011, Article 128402. https://doi.org/10.1155/2011/128402

Liberati, A., Altman, D. G., Tetzlaff, J., Mulrow, C., Gotzsche, P. C., Ioannidis, J. P. A., et al. (2009). The PRISMA statement for reporting systematic reviews and meta-analyses of studies that evaluate healthcare interventions: Explanation and elaboration. British Medical Journal, 2009, Article 339. https://doi. org/10.1136/bmj.b2700

Liem, S., Yuliet, Y., \& Khumaidi, A. (2015). Uji aktivitas antidiabetes kombinasi glibenklamid dan ekstrak daun salam (Syzygium polyanthum Wight.) terhadap mencit (Mus musculus) yang diinduksi aloksan [Antidiabetic activity of glibenclamide and bay leaf extract (Syzygium polyanthum Wight.) combination against mice (Mus musculus) induced by alloxan.]. Jurnal Farmasi Galenika (Galenika Journal of Pharmacy) (e-Journal), 1(1), 42-47.

Loke, A. (2020). Diabetes fact sheet. World Health Organization. Retrieved November 2, 2020, from https:// www.who.int/news-room/fact-sheets/detail/diabetes

Malaysian Herbal Monograph Committee. (2017). Syzygium polyanthum (Wight.) Walp. Retrieved February 27, 2019, from https:/www.globinmed.com/index.php?option=com_content\&view=articl e\&id=106297: syzygium-polyanthum-wight-walp\&catid=209\&Itemid=143. https://www.globinmed. com/index.php?option=com_content\&view=article\&id=106297: syzygium-polyanthum-wightwalp\&catid=209\&Itemid=143

Mohamed, E. A., Ahmad, M., Ang, L. F., Asmawi, M., \& Yam, M. F. (2015). Evaluation of $\alpha$-glucosidase inhibitory effect of 50\% ethanolic standardized extract of Orthosiphon stamineus Benth in normal and streptozotocin-induced diabetic rats. Evidence-Based Complementary and Alternative Medicine, 2015, Article 754931. https://doi.org/10.1155/2015/754931

Nazaruk, J., \& Borzym-Kluczyk, M. (2014). The role of triterpenes in the management of diabetes mellitus and its complications. Phytochemistry Reviews, 14(4), 675-690. https://doi.org/10.1007/s11101-014-9369-x

NHMS. (2019). Non-communicable diseases, healthcare demand and health literacy: Key Findings. National Health and Morbidity Survey 2019. Retrieved November 2, 2020, from http://iptk.moh.gov.my/images/ technical_report/2020/4_Infographic_Booklet_NHMS_2019___English.pdf 
Nwaneri, C., Cooper, H., \& Bowen-Jones, D. (2013). Mortality in type 2 diabetes mellitus: Magnitude of the evidence from a systematic review and meta-analysis. The British Journal of Diabetes \& Vascular Disease, 13(4), 192-207. https://doi.org/10.1177/1474651413495703

Porter, E., Lughadha, E. N., \& Simmonds, M. (2000). Taxonomic significance of polyhydroxyalkaloids in the Myrtaceae. Kew Bulletin, 55(3), 615-632. https://doi.org/10.2307/4118779

Quattrocchi, U. F. L. S. (2012). CRC world dictionary of medicinal and poisonous plants: Common names, scientific names, eponyms, synonyms, and etymology (Vol. V R-Z). CRC Press.

Ramachandran, A., Snehalatha, C., Shetty, A. S., \& Nanditha, A. (2012). Trends in prevalence of diabetes in Asian countries. World journal of Diabetes, 3(6), 110-117. https://doi.org/10.4239/wjd.v3.i6.110

Rashid, F. H. (2017, April 7). Almost 1 in 5 M'sian adults has diabetes: Health Ministry. New Strait Times. Retrieved November 2, 2020, from https://www.nst.com.my/news/2017/04/228106/almost-1-5-msianadults-has-diabetes-health-ministry.

Sumiwi, S. A., Zuhrotun, A., Hendriani, R., Rizal, M., Levita, J., \& Megantara, S. (2019). Subchronic toxicity of ethanol extract of Syzygium polyanthum (Wight) Walp. leaves on Wistar rat. The Indonesian Biomedical Journal, 11(1), 30-35. https://doi.org/10.18585/inabj.v11i1.458

Sutrisna, E., Trisharyanti, I., Munawaroh, R., \& Suprapto, S. (2016). Antioxidant and antidiabetic activity of $70 \%$ ethanolic extract of Syzygium polyanthum (Wight) leaf from Indonesia. International Journal of Research in Ayurveda and Pharmacy, 7, 214-216.

The Plant List. (2012). Syzygium polyanthum (Wight.) Walp. Retrieved February 27, 2019, from http://www. theplantlist.org/tp11.1/record/kew-200120

Velayutham, R., Sankaradoss, N., \& Ahamed, K. N. (2012). Protective effect of tannins from Ficus racemosa in hypercholesterolemia and diabetes induced vascular tissue damage in rats. Asian Pacific Journal of Tropical Medicine, 5(5), 367-373. https://doi.org/10.1016/S1995-7645(12)60061-3

Wahjuni, S., Laksmiwati, A. M., \& Manuaba, I. B. P. (2018). Antidiabetic effects of Indonesian bay leaves (Syzygium polyanthum) extracts through decreasing advanced glycation end products and blood glucose level on alloxan-induced hyperglycemic wistar rats. Asian Journal of Pharmaceutical and Clinical Research, 11(4), 340-343. https://doi.org/10.22159/ajpcr.2018.v11i4.24084

Waly, M. I., Essa, M. M., \& Ali, A. (2010). The global burden of type 2 diabetes: A review. International Journal of Biological \& Medical Research, 1(4), 326-329.

Whiteley, L., Padmanabhan, S., Hole, D., \& Isles, C. (2005). Should diabetes be considered a coronary heart disease risk equivalent? Results from 25 years of follow-up in the Renfrew and Paisley survey. Diabetes Care, 28(7), 1588-1593. https://doi.org/10.2337/diacare.28.7.1588

WHO. (2019). Diabetes mellitus. World Health Organization. Retrieved November 2, 2020, from https://www. who.int/news-room/fact-sheets/detail/diabetes

Widharna, R. M., Tamayanti, W. D., Hendriati, L., Hamid, I. S., \& Widjajakusuma, E. C. (2015). Antidiabetic effect of the aqueous extract mixture of Andrographis paniculata and Syzygium polyanthum leaf. European Journal of Medicinal Plants, 6(2), 82-91. https://doi.org/10.9734/EJMP/2015/15601 
Widyawati, T., Purnawan, W. W., Atangwho, I. J., Yusoff, N. A., Ahmad, M., \& Asmawi, M. Z. (2015a). Antidiabetic activity of Syzygium polyanthum (Wight) leaf extract, the most commonly used herb among diabetic patients in Medan, North Sumatera, Indonesia. International Journal of Pharmaceutical Sciences and Research, 6(4), 1698-1704. https://doi.org/10.13040/IJPSR.0975-8232.6(4).1698-04

Widyawati, T., Yusoff, N. A., Asmawi, M. Z., \& Ahmad, M. (2015b). Antihyperglycemic effect of methanol extract of Syzygium polyanthum (Wight.) leaf in streptozotocin-induced diabetic rats. Nutrients, 7(9), 7764-7780. https://doi.org/10.3390/nu7095365

Yang, D. K., \& Kang, H. S. (2018). Anti-diabetic effect of cotreatment with quercetin and resveratrol in streptozotocin-induced diabetic rats. Biomolecules \& Therapeutics, 26(2), 130-138. https://doi. org/10.4062/biomolther.2017.254

Yuliana, T. W. (2014). Penurunan kadar glukosa darah dan hitung sel Kupffer tikus hiperglikemik setelah pemberian dekok daun salam [Decreased blood glucose levels and Kupffer cell count of hyperglycemic rats after consumption of bay leaf decoction]. Jurnal Veteriner Desember, 15(4), 541-547. 
